\title{
CDH13 wt Allele
}

National Cancer Institute

\section{Source}

National Cancer Institute. CDH13 wt Allele. NCI Thesaurus. Code C51148.

Human CDH13 wild-type allele is located within 16q24.2-q24.3 and is approximately 1170 $\mathrm{kb}$ in length. This allele, which encodes cadherin-13 protein, may be involved in both the mediation of cell-cell interactions in the heart and the inhibition of neuronal cell growth. Hypermethylation or deletion of one or both copies of the gene is associated with many types of cancers. 